\title{
Pandemic Patterns: How Artistic Depictions of Past Epidemics Illuminate Thematic and Structural Responses to COVID-19 Today
}

\author{
Marta Hanson, $P h D^{1,2}$ (1) and Lauren Small, $P h D^{3}$ \\ 'Department of the History of Medicine, Johns Hopkins University School of Medicine, Baltimore, MD, USA; ${ }^{2}$ Max Planck Institute for the History of \\ Science, Berlin, Germany; ${ }^{3}$ Department of Pediatrics, Johns Hopkins University School of Medicine, Baltimore, MD, USA.
}

\begin{abstract}
From the beginning of recorded history, human beings have encountered epidemics. They have also memorialized these events, which can be deeply traumatic and scarring, in visual art and literature. In this article, we look at a selection of artistic depictions of past epidemics in Western culture in light of what they can teach us about COVID-19 today. Our analysis reveals that while responses to epidemics are culturally bound to specific times and places, they also share common features. What surfaces again and again are pandemic patterns: persistent themes, such as divine revelation, "othering," freedom, and exile, girded by a four-part dramaturgical structure as originally articulated by medical historian Charles Rosenberg. We argue that our response to COVID-19 is neither uniformly progressive nor linear, but rather circular or overlapping in time and space. COVID-19 may feel new to us, but in important ways, it is quite old. It has awoken an ancient and durable human script, laid out and reenacted over thousands of years. Understanding these pandemic patterns may help clinicians and health policy makers alike better craft a response to COVID-19 today and to the future epidemics that undoubtedly will come.
\end{abstract}

KEY WORDS: COVID-19 patterns; Epidemics in culture; Pandemic tropes; Dramaturgic structure.

J Gen Intern Med 37(4):878-84

DOI: $10.1007 / \mathrm{s} 11606-021-07214-5$

(C) Society of General Internal Medicine 2021

\section{INTRODUCTION}

When the COVID-19 epidemic emerged in the USA, it seemed to take the population by surprise. People spoke of it as "unprecedented" and "new" ". Indeed, the last time the US faced a global pandemic of this size and scope is outside of living memory: the "forgotten" influenza epidemic of 1918, over a century ago ${ }^{2}$. From the beginning, the public health community took a scientific approach to the virus, collecting data on its infectivity, morbidity, mortality, and the like ${ }^{3}$. But as public health officials will know, such information, while essential, may also be insufficient. For example, it is not

Received August 5, 2021

Accepted October 8, 2021

Published online January 3, 2022 enough to know that masks reduce the spread of the virus if so many people still refuse to wear them. We must understand not just what the epidemic is but how people think and feel about it.

Fortunately, we have a means of gaining this kind of insight. For thousands of years, people have chosen to memorialize encounters with epidemics in visual art and literature. Artistic expression filters the richness of the memory and imagination of an individual's interior life into a cultural representation. Artists make the universal particular and the particular universal. Their representations give us insight into not just how epidemics have affected populations, but also how they have thought and felt about them. By examining artistic depictions of past epidemics in Western culture, we gain valuable insight into COVID-19 today. First, we focus on three themes - divine revelation, blaming outsiders, and limits to freedom - that surface again and again in representations of epidemics. Then, we link these themes with Charles Rosenberg's analysis of the underlying structure of epidemics, crafted in response to the 1980s AIDS epidemic. Rosenberg's four-part dramaturgic structure continues to do useful intellectual work for understanding patterns of human responses to COVID-19. We argue, however, that the structure unfolds neither linearly nor progressively, but rather in a circular and overlapping fashion. Clinicians and historians alike should be aware that people can be simultaneously positioned within any one of an epidemic's "four acts," or even outside of the drama altogether. What becomes clear is how much of our response to COVID-19 is preconditioned by the epidemics that came before it, which may have been individually forgotten, but linger in cultural memory ${ }^{4}$.

\section{THEMES}

\section{Plague as Revelation}

It has become quite common recently to ask what kinds of truths COVID-19 has revealed to us, from the interactions between human beings and the natural world to ongoing questions regarding such troubling issues as structural inequities, healthcare disparities, and social unrest ${ }^{5}$. In ancient times, epidemics were also understood as a source of 
revelation, but of a different kind: a sign of divine will. Epidemics were apocalyptic in the Greek sense of the word, apokaluptein, meaning to uncover or reveal. In Homer's epic poem The Iliad, when the Greeks are struck by pestilence, they understand it to be evidence of Apollo's displeasure: "Let us ask some priest or prophet, or some reader of dreams (for dreams, too, are of Jove) who can tell us why Phoebus Apollo is so angry," Achilles says ${ }^{6}$. The Biblical Book of Exodus recounts ten plagues of various kinds - from disease and death to insect infestations - that God visits on the Egyptians as punishment for their refusal to free their Hebrew slaves. Plague as a sign of divine intervention surfaces repeatedly in the prophetic tradition. Zechariah records a vision of "a man riding a red horse...behind him were other horses - red, chestnut and white," divine messengers sent by God to patrol the world ${ }^{7}$. These messengers appear in Ezekiel as animals representing one of "the four dreadful scourges" of God: "sword, famine, wild beasts and plague" ${ }^{8}$. In Revelation, they take the form of four colored horses signifying death by war, famine, wild beasts, and plague - the "deathly pale" horse ${ }^{9}$.

This image of the four horses of the apocalypse has retained a strong hold on the Western imagination. It appears in artworks by the fifteenth-century German painter and engraver Albrecht Dürer, the eighteenth-century American painter Benjamin West, and the nineteenth-century English poet and painter William Blake, as well as Russian painter Viktor Vasnetsov ${ }^{10-13}$ (Fig. 1). Katherine Anne Porter seized on it when she wrote her semi-autobiographical novella Pale Horse, Pale Rider, based on her experience of the influenza pandemic of 1918. In Porter's conception, the epidemic appears as a stranger that "rode beside her, easily, lightly, his reins loose in his half-closed hand, straight and elegant in dark shabby garments that flapped upon his bones; his pale face smiled in an evil trance, he did not glance at her" ${ }^{14}$. Predictably this image of the four apocalyptic horses has surfaced once again in the COVID-19 pandemic, as some political cartoons demonstrate ${ }^{15}$.
If plague exists in the Western imagination as revelation of divine intervention, then it follows that an epidemic requires a theological cure. In The Iliad, Achilles proposes sacrificing "goats or lambs without blemish" to Apollo in the hope that the god will "take away the plague from us" ${ }^{6}$. As long as the temple still stood in Jerusalem as the center of their priestly cult, Jews offered ketoret incense to God during times of plague ${ }^{16}$. The Book of Numbers tells of a plague that struck the Israelites, only to vanish after the high priest lit incense ${ }^{17}$. After the destruction of the temple, Jews continued to recite the laws and practices pertaining to the incense offering as a means of warding off plague.

This ancient theological understanding of plague has persisted into modern times. In his 1947 novel The Plague, modeled in part on a cholera epidemic, the French writer Albert Camus recounts the story of bubonic plague overcoming a small town. As disease rages unchecked through the town, the priest finally takes matters into his own hands: "[The] ecclesiastical authorities in our town resolved to do battle against the plague with the weapons appropriate to them, and organized a Week of Prayer" ${ }^{18}$. In the summer of 2020, Governor John Bel Edwards of Louisiana called for 3 days of prayer and fasting in response to COVID-19 ${ }^{19}$, one of many religious responses COVID-19 has engendered, including from the Salvation Army ${ }^{20}$ and Pope Francis ${ }^{21}$.

What does the persistence of this theological conception of plague in the face of COVID-19 tell us? The religious impulse is often at odds with the scientific, public health mission. Houses of worship have been successful, for example, in protesting restrictions on the number of persons who can gather indoors for prayer ${ }^{22}$. Hindering a community from gathering to pray may feel like an assault on what they consider to be their most effective spiritual tool against plague. Meanwhile, understanding illness as a sign of divine intervention can also lead to a sense of fatalism; if the outcome is all in God's hands spiritually, what one does materially does not matter. But there are other alternative tenets deeply embedded

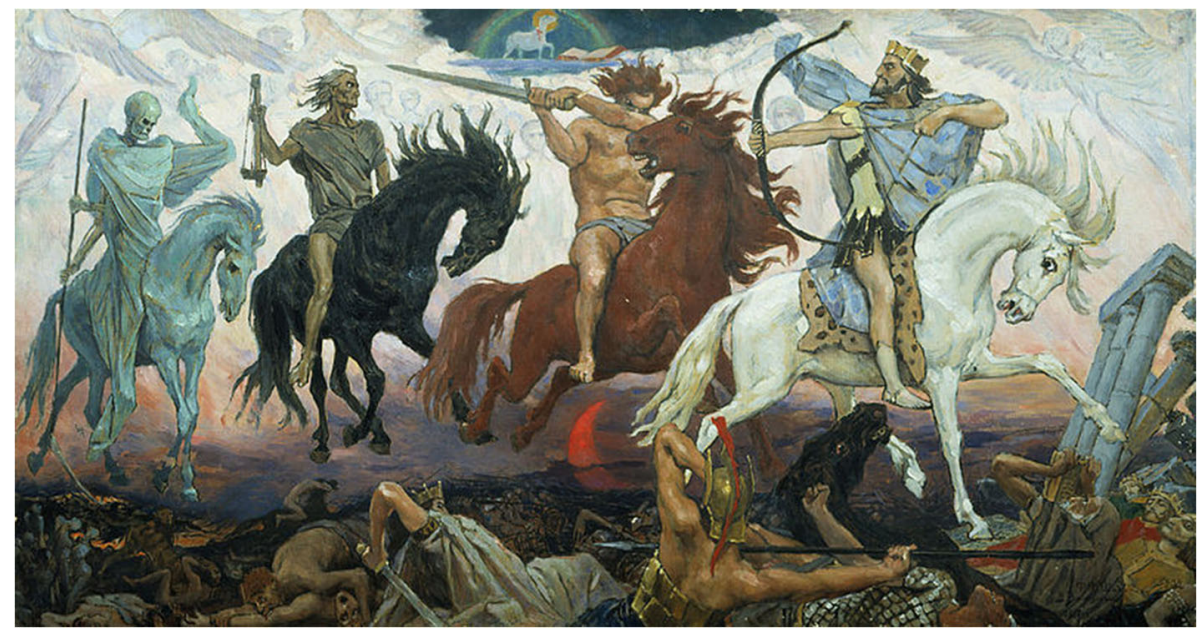

Figure 1. "Four Horsemen of the Apocalypse," 1887, Viktor Vasnetsov (from left to right, the horsemen represent disease, famine, war, and conquest). 
in religious faith that might also be harnessed to foster better compliance with public health measures, such as the imperative to celebrate life, practice compassion, and care for one another, in addition to religious leaders using their networks to disseminate public health messages ${ }^{23}$.

\section{Plague Comes from the Outside}

The idea of plague originating from the outside has long been prominent in the Western imagination. Over two thousand years ago, the Greek historian Thucydides (c. 460-c. 400 $\mathrm{BCE}$ ) emphasized the foreign origin of a plague that struck Athens: "It first began, it is said, in the parts of Ethiopia above Egypt, and thence descended into Egypt and Libya and into most of the King's country. Suddenly falling upon Athens, it first attacked the population in Piraeus, - which was the occasion of their saying that the Peloponnesians had poisoned the reservoirs, there being as yet no wells there $-"{ }^{24}$. The idea that plague arises from poisoning water sources became a persistent trope; in the fourteenth century, Jews - considered outsiders in Medieval Europe - were accused of causing the Black Death by defiling Christian wells ${ }^{25}$.

Death in Venice, the 1912 novella by the German writer Thomas Mann, recounts the story of a man who succumbs to a cholera epidemic, a "plague" that is once again imagined as coming from abroad: "The pestilence," Mann writes, "originated in the warm swamps of the Ganges delta, rising on the foul-smelling air" ${ }^{26}$. Porter's novella, which takes place during World War I, also imagines an outside source for influenza, in this case the enemy, Germany: "They say... that it is really caused by germs brought by a German ship" ${ }^{27}$. In Camus's novel, China emerges as a likely culprit for the bubonic plague that affects the town, as one character recounts: "I was in China for a good part of my career, and I saw some cases in Paris... Only no one dared to call them by their name...The usual taboo" 28 .

Today, China has emerged again in the popular imagination as a source of disease, with many people calling COVID-19 the "Wuhan virus," "Kung Flu," or "Chinese virus." This "othering" of the virus has significant repercussions. It does not merely emphasize that the first known outbreak of the current pandemic occurred in Wuhan ${ }^{29}$, but also falsely ascribes blame to others and distracts public attention from failures to control community spread after its US arrival ${ }^{30}$. Meanwhile, since the epidemic began, Asian-Americans have experienced rising violence ${ }^{31}$. They are not the only domestic group to be accused of causing COVID-19. Other groups that are viewed as outsiders have also been blamed for the virus - usually the most vulnerable and so least able to protect themselves ${ }^{32}$.

Ascribing blame to others may make some communities feel no need to take measures to protect themselves. Furthermore, those with the political or financial means to do so may attempt to sequester themselves away ${ }^{33}$. They replay the scenario that occurs in Edgar Allan Poe's 1842 short story
"The Masque of the Red Death," where a prince invites his guests to take refuge in an abbey against an epidemic, only to find death visits them after all ${ }^{34}$. Such conceptions of the "other" can contribute to further outbreaks, such as the one within the White House and among some legislators ${ }^{35}$. On the other hand, "othering" can also inform misguided public health policies, such as using COVID-19 in arguments to block entry for asylum seekers ${ }^{36}$ even though "jet-setters" in power and privilege were the people who initially transmitted it ${ }^{37}$. Recognizing the "othering" of disease as a persistent Western trope can help us better understand the COVID-19 social and political environment today, and so craft more equitable responses.

\section{Freedom and Exile}

The emergence of COVID-19 in the USA has engendered a complex and passionate debate on personal freedoms and liberty. While people resent "lockdowns," closures, and other restrictions for their disruption of social and economic life, nothing has emerged as a more potent symbol against public health measures than wearing masks ${ }^{38}$. Protests against masks are nothing new, but simply one more aspect of the many patterns that accompany epidemics. Similar protests occurred over a century ago during the influenza epidemic ${ }^{39}$. Even vaccine hesitancy has long roots in Western life, dating back at least to the nineteenth century ${ }^{40}$. Many who oppose public health measures in the USA view them as infringements on their personal liberty rather than as means to contribute to the collective good ${ }^{41}$. Ultimately, such protests in favor of freedom are intensely misguided. It is not public health but the epidemic, with its threat of illness and death, that deprives all of essential liberties. Masks and vaccines, which have the potential to combat and finally vanquish the virus, are the keys to returning to a more normal life. Anyone who has experienced even in a limited way the relief that comes through being fully vaccinated can attest to this fact.

The freedom that we lose in an epidemic goes well beyond simple acts of gathering, shopping, and traveling; we lose the freedom to be ourselves. As Harvard historian Jill Lepore has noted, stories of epidemics teach us that during times of plague "[h]umans lose their humanity" ${ }^{42}$. Plague disrupts. It forces us into personal and social isolation, impacting our perception of time, memory, and connection. "The first thing that plague brought to our town was exile..." Camus writes, "that sensation of a void within which never left us, that irrational longing to hark back to the past or else to speed up the march of time" ${ }^{43}$. Mann's protagonist, normally a rational man, undergoes a deeply unsettling transformation during the Venetian cholera epidemic; despite knowing that " $[\mathrm{t}] \mathrm{o}$ remain in place obviously went against all reason" ${ }^{44}$, he decides to stay in the diseaseriddled city. Ultimately, plague shakes him to the core, rendering him alienated from himself, so that he experiences a "lack of knowledge of his own desires" ${ }^{45}$. In Camus's novel, the doctor fighting plague feels as if his "heart had slowly 
closed in on itself" ${ }^{46}$, while his town becomes "a defunct city in which plague, stone, and darkness had effectively silenced every voice" ${ }^{47}$.

The economic disruption we have seen from COVID-19 is nothing new. Porter writes: "It's as bad as anything can be...all the theaters and nearly all the shops and restaurants are closed" ${ }^{48}$. In the Venice of Mann's novel, officials conspire to cover up the cholera epidemic in order to protect the tourist trade: "[T]he city was sick and was keeping its secret out of pure greed" 49 . Camus describes "neglected heaps of sack and barrels - all testified that commerce, too, had died of plague"

${ }^{50}$. Perhaps exacerbated by economic woes, social unrest, such as the kind we have seen over the past year in the USA, often travels in the wake of epidemics ${ }^{51}$. In Camus's novel, citizens rebelling against the imposition of a forced quarantine make "frequent attacks on the gates of the town, and the men who made them now were armed" ${ }^{52}$. While it may be impossible to quantify, the vast amount of social unrest we have witnessed in the USA from the beginning of the COVID-19 epidemic to today surely results in part from its social and political effects. This conflict reaches expression in Camus's novel as well. Plague, the French writer tells us, tears at the social and economic fabric, striking at the heart of our ability to act as autonomous agents: As Camus writes: "They fancied themselves free, and no one will ever be free so long as there are pestilences" 53 .

How the current pandemic will end remains to be seen. What the post-pandemic world will look like will inevitably be uneven and variable across the USA as in the world. There is some evidence that repercussions from the social, psychological, and economic disruptions of the virus, like aftershocks in an earthquake, will be felt for some time ${ }^{54}$. We yearn for a return not just to "normal" life but to ourselves. As Lepore, waiting for her own vaccine, asks, "Do the humans get to be human again?" 55 .

\section{STRUCTURE}

\section{Epidemics as Four-part Dramas}

The COVID-19 epidemic is not only thematically similar to past epidemics; it also shares an underlying structure. In response to the 1980s AIDS epidemic, medical historian Charles Rosenberg outlined a common structure that could be productively applied to all epidemics - including their inevitable dénouement: "[A]s a social phenomenon, an epidemic has a dramaturgic form. Epidemics start at a moment in time, proceed on a stage limited in space and duration, following a plot line of increasing and revelatory tension, move to a crisis of individual and collective character, then drift toward closure" 56 .

Rosenberg interprets epidemics as a social phenomenon, an event rather than a trend that takes dramaturgical form, like a play unfolding in four acts: they begin with progressive revelation, then move through managing randomness before shifting to negotiating a public response, and, finally, conclude into subsidence and retrospection. The three themes outlined above-divine revelation, "othering," freedom and exile-appear within these acts. This dramaturgic structure surfaces most vividly in Camus's novel, for example, where the people of the town begin by denying the existence of plague, struggle to explain it, make numerous ineffective attempts to contain it, until finally, as inexplicably as it came, the epidemic disappears.

Many scholars have put Rosenberg's four-part dramaturgic structure to work as an analytical tool to understand the range of present responses to COVID-19. As early as March 2020, a sociologist cited Rosenberg to argue that COVID-19 shares with all other past epidemics the trait that "all of them are at once diseases of the physical and the social body" 57 . By April, another scholar used Rosenberg's analysis of epidemics as a sampling device for studying underlying fissures in the social fabric ${ }^{58}$. By summer, another scholar deployed the four-act model to uncover similarities among epidemics as well as variety of responses within them at different times and places ${ }^{59}$. Other scholars reconsidered the fourth act as more about forgetting, or relegating the problem to someone else, than a foregone conclusion or even dénouement ${ }^{60}$. Developing further upon Rosenberg's foundations, other historians reflected on how history is being used to cover COVID-19 and who gets to tell the story of epidemics and decide when this one will end ${ }^{61}$. Rosenberg even weighed in by emphasizing that epidemics differ from other diseases in both their novelty and the fear they inspire, sometimes disproportionate to the relative death they cause, as was the case between the more greatly feared cholera in contrast to the more deadly tuberculosis ${ }^{62}$.

\section{Non-linearity, Simultaneity, and Denial}

Rosenberg's four-act structure has clearly been productive for understanding our pandemic present. No one, however, has reconsidered its linear order. Epidemics do not occur in as predictable ways as pre-scripted plays or well-structured novels. At times the four stages seem to succeed one another in orderly linear fashion; at other times, however, they overlap and collide, like scripted flashbacks intended for dramatic effect that bring to the surface of consciousness deep societal fissures. Some portions of our society, for example, had long accepted the existence of the coronavirus epidemic (act 1), while others, even well after a year of the pandemic, and despite the undeniable evidence of catastrophic illness and premature deaths, had not. It is hard to coordinate a national response (act 3 ) when segments of the population are still actively engaged in progressive revelation (act 1$)^{63}$. While some, because of their positions in government, public health, and medicine, must continuously adjust responses to randomness (act 2), still others are already conceptualizing postpandemic possibilities (act 4) ${ }^{64}$.

We find analogies for this simultaneity of acts in literature, for example, William Faulkner's novel The Sound and The 
Fury. Faulkner structured his account of one southern aristocratic family's inevitable decline by centering its four nonsequential chapters on four different perspectives. By weaving into each chapter key episodes in the family's decline, Faulkner highlighted contrasting perspectives from opposing positions within and vis-à-vis the family. With this nonlinear narrative strategy, Faulkner succeeded to demonstrate the simultaneity of different positions within the linear arch of one family's dissolution.

Although Rosenberg's dramaturgic structure of epidemics is linear, how people experience epidemics is not necessarily so, because where they are positioned within these acts can be simultaneous. To push the theme of social-familial-racial positioning in Faulkner's work further, not all possible social responses can even be classified within one of these four acts. The parallel infodemic of misinformation, for instance, has led many to believe conspiracy theories characterizing the epidemic as being intentionally unleashed for nefarious ends or even being just a hoax ${ }^{65}$. Those who embrace the sinister theory fit well within "managing randomness" (act 2). COVID-19 deniers, however, conceptually position themselves outside of the epidemic, even though corporeally this is not possible ${ }^{66}$. They walked out of the play, refusing to bear witness to the drama. They have free tickets for the daily performance but have neither intention to attend nor interest to comprehend. In short, Rosenberg's original analysis could be further improved by acknowledging the possibility of both simultaneous acts based on different positions within the epidemic and conceptual positioning outside the epidemic altogether.

\section{EPIDEMIC EPILOGUES}

Nonetheless, the good news that Rosenberg's 1990s analysis of the AIDS epidemic delivers 30 years later for our COVID-19 present is that epidemics invariably end. This is true even if the nature of their ending is far from predictable or controllable: "Epidemics ordinarily end with a whimper, not a bang. Susceptible individuals flee, die, or recover, and incidence of the disease gradually declines. It is a flat and ambiguous yet inevitable sequence for a last act" ${ }^{67}$. The close of an epidemic, he continues, provides us with an opportunity for retrospection, "an implicit moral structure that can be imposed as an epilogue" 67 .

As the influenza epidemic and World War I come to a close, Porter's narrator reflects as she leaves the hospital - just at the moment she loses contact with her lover's shade and with it what should have been their future together: "No more war, no more plague, only the dazed silence that follows the ceasing of the heavy guns; noiseless houses with shades drawn, empty streets, the dead cold light of tomorrow. Now there would be time for everything" ${ }^{68}$. Already we can see the impulse to salvage something good from the COVID-19 experience among people who talk about how the epidemic has encouraged them to focus on the values that matter most to them ${ }^{69}$. COVID-19 has significantly influenced health policy debates in this country, for example, especially related to underinvestment in public health infrastructure ${ }^{70}$. No doubt this pandemic will have lasting repercussions. Ultimately, how it will influence our political, communal, and social institutions remains to be seen, though what remains clear is that all four acts of this pandemic's underlying structure will remain simultaneously performed somewhere, until we either reach herd immunity, or vaccinations collectively shepherd us into COVID-19's final act.

\section{CONCLUSION}

Epidemics exist in a space between remembering and forgetting, between memory and oblivion. The influenza epidemic of 1918 has been called the forgotten epidemic because of how eagerly those who suffered through it put it aside ${ }^{71}$. Even today people speak longingly of "just wanting to get back to normal," and "putting this all behind us" ${ }^{72}$. While this impulse to forget is understandable, it can be deleterious to sustained public health strategies, leaving us with a pattern of "panic, neglect, panic" ${ }^{73}$. In any case, epidemics, as we know from their depictions in visual art and literature, are only imperfectly and temporally forgotten. They etch deep scars in the human psyche. In the words again of Camus: "[O]ne can't forget everything, however great one's wish to do so; the plague was bound to leave traces... in people's hearts" 74 .

On the $28^{\text {th }}$ of October in 1918 , the day before his wife died of influenza, the Austrian artist Egon Schiele sketched her portrait ${ }^{75}$. Three days later he, too, died. The portrait lives on, an enduring tribute to love within context of grief. Artists of today are also well into act 4 by chronicling their encounters

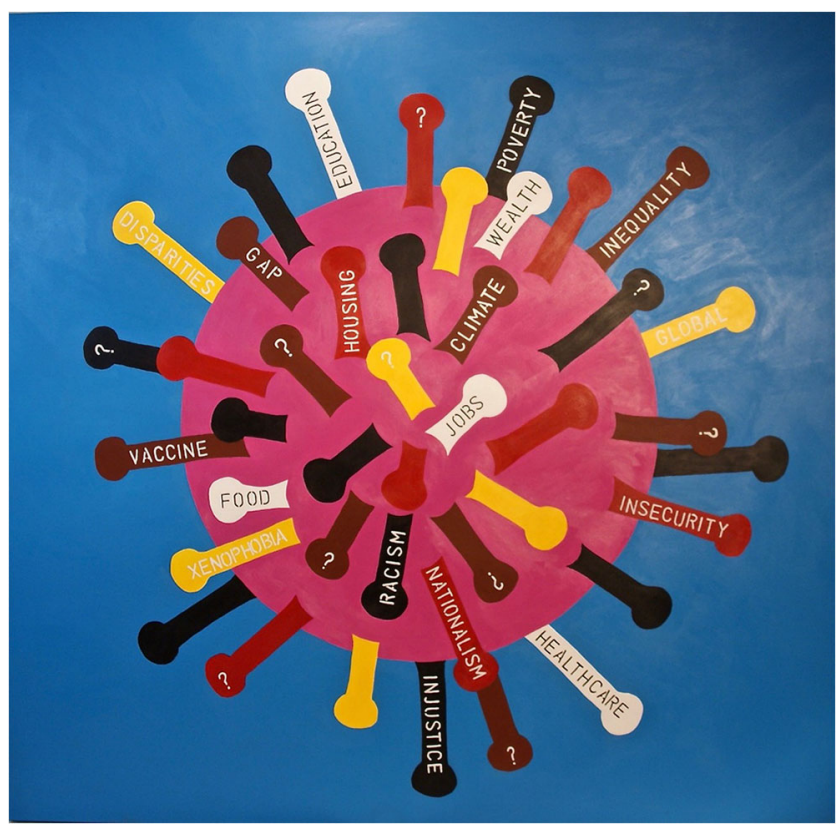

Figure 2. "Some Hoax!" 2021, Kelly Burke. The five colors of humanity visualize that more people of color than Caucasians have been dying from COVID-19 and the words express the complex reasons why. 
with COVID-19 through fiction ${ }^{76}$ and visual art ${ }^{77}$, though it remains to be seen whether their insights will reframe epidemic narratives (Fig. 2). Plague, Camus says, "means exactly that - the same thing over and over and over again" ${ }^{78}$. But perhaps with greater insight into the central themes and structure that have characterized epidemics throughout history, we can break these patterns and act more effectively within whichever one of the four acts we, or the people we observe, find ourselves in. The themes and structure of epidemic patterns, as captured by previous artists, remain for us a conceptual means for more productive ends out of our COVID-19 present, and hopefully will better prepare us for the future epidemics that invariably will come. Thequestion marks and blank spikes invite viewers to fill in the blanks with words that summarize what COVID-19 hasrevealed for them.

Acknowledgements: The authors thank the AfterWards program at Johns Hopkins University for providing the first opportunity to present our work as well as the close attention to clarity of expression and many insightful comments of the JGIM journal editors and anonymous reviewers. Our AfterWards audience and reviewers collectively improved this article.

Corresponding Author: Marta Hanson, PhD; Department of the History of Medicine, Johns Hopkins University School of Medicine, Baltimore, MD, USA (e-mail: ).

Declarations:

Conflict of Interest: The authors declare that they do not have a conflict of interest.

\section{REFERENCES}

1. Archives of Community Medicine and Public Health. COVID-19: an unprecedented crisis that needs an extraordinary response. Available at: https://www.peertechzpublications.com/articles/ACMPH-6-175.php. Accessed January 30, 2021.

2. Crosby A W. America's forgotten pandemic: the influenza of 1918 Cambridge: Cambridge University Press; 2003. https://doi.org/10. 1017/CBO9780511586576

3. Johns Hopkins University and Medicine Coronavirus Resource Center. Available at: https://coronavirus.jhu.edu/map.html. Accessed October 10, 2020.

4. Fissell M. Pandemics come and go. The way people respond to them barely changes: Coronavirus is hitting our society the same way the bubonic plague hit England in 1665. Washington Post. 7 May 2020 Available at: https://www.washingtonpost.com/outlook/2020/05/07/ coronavirus-bubonic-plague-london/. Accessed on January 30, 2021.

5. Freeland $\mathbf{J}$. The magnifying glass: how Covid revealed the truth about our world. The guardian. Available at: https://www.theguardian.com/ world/2020/dec/11/covid-upturned-planet-freedland. Accessed April 6 , 2021.

6. The Iliad of Homer, rendered into English prose for the use of those who cannot read the original. Trans. Samuel Butler. London/New York/Bombay: Longmans, Green, and Co.; 1898. Book I: Achilles and Oalchas 3, 23. Full 1898 text available from babel.hathitrust.org Available at: https://babel.hathitrust.org/cgi/pt?id=cool.ark:/13960/ t1zc8h28j\&view=1up\&seq=7. Accessed January 30, 2021

7. Zechariah 1: 8-11. The New Jerusalem Bible. New York: Doubleday; 1985:1593. Available at: https://babel.hathitrust.org/cgi/pt?id=umn. 31951p00477700i\&view=1up\&seq=7. Accessed January 30, 2021.

8. Ezekiel 14:21. The Jerusalem Bible. New York: Doubleday; 1985:14191420. Available at: https://babel.hathitrust.org/cgi/pt?id=umn. 31951p00477700i\&view=lup\&seq=7. Accessed January 30, 2021.

9. Revelation 6:1-8. The New Jerusalem Bible. New York: Doubleday; 1985:2036. Available at: https://babel.hathitrust.org/cgi/pt?id=umn 31951p00477700i\&view=1up\&seq=7. Accessed January 30, 2021.

10. Dürer A. The Four Horseman of the Apocalypse. Available at: https:// commons.wikimedia.org/wiki/File:Albrecht_d\%C3\%BCrer,_i_quattro_ cavalieri_dell\%27apocalisse,_1497-98,_02.jpg. Accessed September 2, 2021.

11. West, B. Death on The Pale Horse. Available at: https://commons. wikimedia.org/wiki/File:Benjamin_West_-_Death_on_the_Pale_Horse__79.33_-_Detroit_Institute_of_Arts.jpg. Assessed September 2, 2021.

12. Blake W. Death on a Pale Horse. Available at: https://commons. wikimedia.org/wiki/File:William_Blake_-_Death_on_a_Pale_Horse__Butlin_517.jpg. Accessed September 2, 2021.

13. Vasnetsov V. Four Horsemen of Apocalypse. Available at: https:// commons.wikimedia.org/wiki/File:Apocalypse_vasnetsov.jpg. Accessed January 30, 2021

14. Porter KA. Pale Horse Pale Rider. Florida: Harcourt Brace; 1939:143.

15. Archibald A. The four horsemen of the apocalypse are tiring of Trump. Pax on both houses. Available at: http://paxonbothhouses.blogspot. com/2018/11/cartoon-four-horsemen-of-apocalypse-are.html. Accessed January 30, 2021

16. Exodus 30: 1. The Jerusalem Bible. New York: Doubleday; 1966:93-94.

17. Numbers 16: 46-48. The Jerusalem Bible. New York: Doubleday; 1966:141-187.

18. Camus A. The Plague. New York: Random House; 1948:92.

19. Gov. John Bel Edwards calls for three days of prayer, fasting because of COVID-19. WDSU News. 20 July 2020. Available at: https://www. wdsu.com/article/gov-john-bel-edwards-calls-for-three-days-of-prayerfasting-because-of-covid-19/33368262. Accessed September 9, 2020.

20. Covid-19 prayer resources. The Salvation Army. Available at: https:// www.salvationarmy.org/ihq/covid19-prayer. Accessed April 6, 2021.

21. Covid-19: Faithful respond to Pope's invitation to pray on May 14. Vatican news. Available at: https://www.vaticannews.va/en/church/ news/2020-05/covid-19-faithful-respond-to-popes-invitation-to-praymay-14.html Accessed on April 6, 2021

22. Howe A. Justices revive religious groups' attempts to block COVIDrelated restrictions in Colorado, New Jersey. Supreme Court of the Unites States Blog. 15 December 2020. Available at: https://www.scotusblog. com/2020/12/justices-revive-religious-groups-attempts-to-block-covidrelated-restrictions-in-colorado-new-jersey/. Accessed on January 4, 2021.

23. Barmania S, Reiss $\mathbf{M J}(2020)$ How religion can aid public health messaging during a pandemic: Religious leaders have distinctive networks that can help disseminate important messages in the COVID-19 crisis. Nature India. 20 May 2020. Available at: https:// www.natureasia.com/en/nindia/article/ https://doi.org/10.1038/ nindia.2020.87. Accessed January 30., 2021.

24. Thucydides. History of the Peloponnesian War. Trans. Richard Crawley. London: J. M. Dent \& Sons, Ltd; New York: E. P. Dutton \& Co; 1914: Book II, Chapter VII, 48 [129].

25. Foa A. The Jews of Europe After the Black Death. Berkeley: Univ of California Pr; 2000: 146. See also Barzilay T. Early Accusations of Well Poisoning against Jews: Medieval Reality or Historiographical Fiction? Medieval Encounters. 2016; 22(5):517-39. doi.org/https://doi.org/10. 1163/15700674-12342236.

26. Mann T. Death in Venice. New York: Random House; 1930:53.

27. Porter K A. Pale Horse Pale Rider. Florida: Harcourt Brace; 1939:162163.

28. Camus A. The Plague. New York: Random House; 1948:35

29. Mohan BS, Nambiar V. COVID-19: An Insight into SARS-CoV-2 Pandemic Originated at Wuhan City in Hubei Province of China. J Infect Dis Epidemiol. 2020; 6:146.

30. White IRW and King KQ. The U.S. has an ugly history of blaming 'foreigners' for disease: That attitude can spread more quickly than a virus. Washington Post. 24 March 2020. Available at: https://www. washingtonpost.com/politics/2020/03/24/us-has-an-ugly-historyblaming-foreigners-disease/. Accessed on January 30, 2021.

31. Nabong P. 'Trauma upon trauma': Asian Americans say mental health has suffered amid COVID-19, anti-Asian violence. 9 April 2021 Available at: https://chicago.suntimes.com/politics/2021/4/9/22372260/asianamericans-mental-health-covid-pandemic-violence-chicago-atlanta Accessed on April 9, 2021.

32. What is the impact of the COVID-19 pandemic on immigrants and their children? OECD policy responses to coronavirus (COVID-19). 19 October 2020. Available at: https://www.oecd.org/coronavirus/policyresponses/what-is-the-impact-of-the-covid-19-pandemic-on-immigrants-and-their-children-e7cbb7de/. Accessed on January 15, 2021.

33. Robson M. How the rich and famous escape the pandemic. 27 December 2021. Available at: https://www.forbes.com/sites/michelerobson/2021/ $12 / 27$ / how-the-rich-famous-escape-the-pandemic/? sh=255464905521. Accessed April 9, 2021. 
34. Poe EA. The Masque of the Red Death. Available at: https://www. gutenberg.org/files/1064/1064-h/1064-h.htm. Accessed January 30, 2021.

35. White House hosted Covid 'super spreader' event says Dr. Fauci. BBC News. Available at: https://www.bbc.com/news/election-us-202054487154. Accessed April 9, 2021.

36. Peeler KR and S Podolsky. "COVID-19, Asylum, and False Binaries of Detention. Health and Human Rights Journal 9 June 2020. Available at: https://www.hhrjournal.org/2020/06/covid-19-asylum-and-false-binaries-of-detention/ . Accessed July 25, 2021.

37. Beaubien J. COVID-19's Global Spread Among The Relatively Rich Has Been Remarkable. National Public Radio, Weekend Edition Sunday. 14 March 2020. Available at: https://www.npr.org/2020/03/15/ 815828858/coronavirus-and-the-rich-beaubien Accessed July 25, 2021.

38. Pearkes G. The fight over masks is really a debate over how Americans view our fundamental freedoms. Business Insider. 30 August 2020. Available at: https://www.businessinsider.com/fight-anti-masks-coronavirus-pandemic-freedom-us-politics-2020-8. Accessed April 9, 2021.

39. Navarro JA. Mask resistance during a pandemic isn't new-in 1918 many Americans were 'slackers.' The Conversation. 13 July 2020. Available at: https://theconversation.com/mask-resistance-during-apandemic-isnt-new-in-1918-many-americans-were-slackers- 141687. Accessed on January 30, 2021. See also Dolan B. Unmasking history: who was behind the anti-mask league protests during the 1918 influenza epidemic in San Francisco? Perspectives in Medical Humanities (UC Medical Humanities Consortium, May 19, 2020). https://doi.org/10. 34947/M7QP4M.

40. Porter $\mathbf{D}$ and $\mathbf{R}$. Porter. The politics of prevention: anti-vaccination and public health in $19^{\text {th }}$-century England. Medical History. 1988;32:231252.

41. Bayer $\mathbf{R}$. The continuing tensions between individual rights and public health. Talking Point on public health versus civil liberties. EMBO Rep. 2007 Dec 8; 12:1099-1103.https://doi.org/10.1038/sj.embor.7401134. [PMID: 18059307]

42. Lepore J. How do plague stories end? The New Yorker. 24 March 2021.

43. Camus A. The Plague. New York: Random House; 1948:71

44. Mann T. Death in Venice. New York: Random House; 1930:30.

45. Mann T. Death in Venice. New York: Random House; 1930:34.

46. Camus A. The Plague. New York: Random House; 1948:91.

47. Camus A. The Plague. New York: Random House; 1948:172.

48. Porter KA. Pale Horse Pale Rider. Florida: Harcourt Brace; 1939:184.

49. Mann T. Death in Venice. New York: Random House; 1930:47.

50. Camus A. The Plague. New York: Random House; 1948:77.

51. Galea S. and SM Abdalla. COVID-19 Pandemic, Unemployment, and Civil Unrest: Underlying Deep Racial and Socioeconomic Divides. JAMA. 2020;324(3):227-228. doi: https://doi.org/10.1001/ jama.2020.11132.

52. Camus A. The Plague. New York: Random House; 1948:177.

53. Camus A. The Plague. New York: Random House; 1948:37.

54. Gander $\mathbf{J}$. History tells us epidemics are followed by huge civil unrest for these three reasons. Newsweek. Available at: https://www.newsweek. com/history-epidemics-pandemic-civil-unrest-reasons-1530055. Accessed April 9, 2021.

55. Lepore J. How do plague stories end? The New Yorker. 3.24.2021. Available at: https://www.newyorker.com/books/page-turner/how-doplague-stories-end. Accessed April 9, 2021.

56. Rosenberg CE. What Is an Epidemic? AIDS in Historical Perspective. Daedalus 118.2 (1989): 1-17. Republished as ch. 13 in Rosenberg CE. Explaining Epidemics. Cambridge, England: Cambridge University Press, 1992: 279.

57. Shapin S. COVID and Community. Los Angeles Review of Books. March 30, 2020. Available at: https://lareviewofbooks.org/article/covidand-community/. Accessed May 21, 2021

58. Jones DS. History in a Crisis - Lessons for Covid-19" N Engl J Med 382:18 April 30, 2020 Available at: https://www-nejmorg.proxy l.library.jhu.edu/doi/pdf/https://doi.org/10.1056/ NEJMp2004361?articleTools=true. Assessed May 21, 2021.

59. Charters E and RA McKay. The history of science and medicine in the context of COVID-19. Centaurus 2020;62:223-233. Accessed at https:// onlinelibrary-wiley-com.proxy 1.library.jhu.edu/doi/epdf/https://doi. org/10.1111/1600-0498.12311. Accessed May 21, 2021.
60. Greene JA and D Vargha. How Epidemics End. Boston Review June 30, 2020. Available at: http://bostonreview.net/science-nature/jeremygreene-dora-vargha-how-epidemics-end. Accessed May 21, 2021.

61. Landstaff A. Pandemic Narratives and the Historian. Los Angeles Review of Books. May 18, 2020. Available at: https://lareviewofbooks.org/ article/pandemic-narratives-and-the-historian/. Accessed May 21, 2021.

62. Rosenberg CE. Shaping a Pandemic Narrative. Social Research: An International Quarterly 2020; 87(2): 287-288.

63. Wolfe D. and D. Dale. It's going to disappear: a timeline of Trump's claims that COVID-19 will vanish. CNN. 31 Oct 2020. Available at: https://www.cnn.com/interactive/2020/10/politics/coviddisappearing-trump-comment-tracker/. Accessed January 16, 2021.

64. Zakaria F. Ten Lessons for a Post-pandemic World. New York: W.W. Norton; 2020.

65. Imhoff R. and PA Lamberty. Bioweapon or a Hoax? The Link Between Distinct Conspiracy Beliefs About the Coronavirus Disease (COVID-19) Outbreak and Pandemic Behavior. Soc Psychol Personal Sci. 6 Jul 2020. Available at: https://www.ncbi.nlm.nih.gov/pmc/articles / PMC7342934/. Accessed July 2, 2021.

66. Saslow E. 'What are we so afraid of?' Tony Green, on dismissing, denying, contracting and spreading the coronavirus. 10 October 2020. Available at: https://www.washingtonpost.com/nation/2020/10/10/coronavirus-denier-sick-spreader/. Accessed July 25, 2021.

67. Rosenberg CE. What Is an Epidemic? AIDS in Historical Perspective. Daedalus. 1989; 118(2):1-17. Republished as ch. 13 in Rosenberg CE. Explaining Epidemics. Cambridge, England: Cambridge University Press; 1992:286.

68. Porter KA. Pale Horse Pale Rider. Florida: Harcourt Brace; 1939:208

69. Bulaong $\mathbf{O}$. Reflections in a time of quarantine. Markkula Center for applied ethics at Santa Clara University. Available at: https://www.scu. edu/ethics-spotlight/covid-19/reflections-in-a-time-of-quarantine/. Accessed January 18, 2021.

70. Manni N. and S. Galea.COVID-19 and Underinvestment in the Public Health Infrastructure of the United States. The Milbank Quarterly. May 2020; 98: DOI: https://doi.org/10.1111/1468-0009.12463 Available at: https://www.milbank.org/quarterly/articles/covid-19-and-underinvestment-in-the-public-health-infrastructure-of-the-united-states/. Accessed July 25, 2021.

71. Spinney L. Pale Rider: The 1918 Spanish Flu and How it Changed the World. London: Jonathan Cape; 2017.

72. Cunningham PW. When will 2021 feel normal again? Here's what eight experts predict. The Washington Post. 4 January 2021. Available at: https://www.washingtonpost.com/politics/2021/01/04/health-202when-will-202 1-feel-normal-again-here-what-eight-experts-predict/. Accessed January 4, 2021.

73. Yong E. The Deadly Panic-Neglect Cycle in Pandemic Funding. The Atlantic. 24 October 2017. Available at: https://www.theatlantic.com/ science/archive/2017/10/panic-neglect-pandemic-funding/543696/. Accessed January 18, 2021.

74. Camus A. The Plague. New York: Random House; 1948:280.

75. Schiele E. Portrait of Edith. Available at: https://commons.wikimedia. org/w/index.php?search=Egon +Schiele++portrait +of + edith\&title=Special:Search\&profile=advanced \&fulltext $=1$ \&advancedSearch - current $=\% 7$ B \% 7 D \& n s $0=1 \&$ ns $6=1$ \&ns $12=1$ \& ns $14=$ $1 \&$ ns $100=1 \&$ ns 106=1\#/media/File:Schiele_-_Edith_Schiele_sterbend_1918.jpg. Accessed January 30, 2021.

76. Moore L. Face Time. The New Yorker. 28 September 2020. Also, Doyle R. Roddy Doyle on writing from the pandemic. The New Yorker. 12 October 2020.

77. Art in the Time of Corona: A Global Art Project. Available at: https:// www.dabart.me/art-in-the-time-of-corona. Accessed January 30, 2021. Burke K. "Some Hoax!" Available at: https://kellyburke-artworks.com/. Accessed September 2, 2021. Painting published in catalogue for exhibition "SOS Planet Earth," Stola Contemporary Art, Chicago, July 30-Sept 12, 2021. Available at: https://www.amazon.com/dp/ B09B7FSJHQ?ref_=pe_3052080_397514860. Accessed September 14, 2021.

78. Camus A. The Plague. New York: Random House; 1948:161.

Publisher's Note Springer Nature remains neutral with regard to jurisdictional claims in published maps and institutional affiliations. 